\title{
Literary StUdies In ROMANIA Before AND After 1989
}

\author{
Estudos literáRIOS NA ROMÊNIA
}

ANTES E DEPOIS DE 1989

\author{
Ana-Karina Schneider \\ Universidade Lucian Blaga \\ Sibiu, Romênia
}

Palavras-chave: Estudos Anglófonos; livros-didáticos; tradução literária; política cultural; anglocentrismo.

Keywords: English studies, textbooks, literary translation, cultural politics, Anglocentricity.

Cuvinte cheie: Studii Anglofone, manuale, traducere literară, politici culturale, anglocentricitate.

\section{Resumo}

Em termos comparativos, após as rígidas políticas culturais e a censura imposta pelo regime comunista, a literatura e os estudos literários da Romênia pós-comunista pareceriam ser quase que totalmente desprovidos de política. O presente artigo investiga as complexas maneiras pelas quais vários aspectos do estudo e da recepção da literatura inglesa - desde a prática de ensino do inglês, passando por livros didáticos, até chegar à tradução literária - refletem a evolução da relação entre literatura e política na Romênia pré e pós-1989. Na troca cultural assimétrica que resulta da inevitável hierarquia na qual a cultura Anglo-Americana é dominante, enquanto a cultura romena é perpetuamente subordinada, está última abraça sua marginalidade, situando-se estrategicamente do lado da recepçáo. Argumento que, se por um lado a preocupação de pesquisadores Anglo-Americanos com os efeitos perniciosos do anglocentrismo no Estudos Anglófonos é em si uma postura ética louvável, em culturas como a romena, o anglocentrismo pode funcionar como um catalisador de resistência e mudança.

\section{Abstract}

In comparative terms, after the strict cultural policies and censorship of the communist regime, the literature and literary studies of post-communist Romania would seem to be almost completely free of the political. This article investigates the complex ways in which various aspects of the study and reception of English literature from the practice of teaching English, through textbooks, to literary translation - reflect the evolution of the relationship between litera-

\section{Rezumat}

În termeni relativi, după politicile culturale și cenzura strictă a regimului comunist, literatura și studiile literare din Romania post-comunistă par a fi aproape complet lipsite de ingerințe politice. Acest articol investighează modul complex în care diverse aspecte ale studiului și receptării literaturii anglofone - de la practici didactice și manuale la traducere literară - reflectă evoluția relației dintre literatură și politică în Romania pre- și post-1989. În schimbul asimetric ce rezultă 
ture and politics in pre- and post1989 Romania. In the asymmetrical cultural exchange resulting from the inevitable hierarchy in which Anglo-American culture is dominant, whereas Romanian culture is perpetually subordinate, the latter embraces its marginality and places itself strategically at the receiving end. I therefore argue that while Anglo-American scholars' concern with the pernicious outcomes of Anglocentricity in ES is in itself a laudable ethical move, in target cultures such as the Romanian, Anglocentricity may function as a catalyst of resistance and change. din ierarhia inerentă a culturilor, in care culturile anglo-americane sunt dominante, în timp ce cultura românească este veșnic subordonată, aceasta din urmă ị̂i asumă propria marginalitate şi se plasează strategic în poziția de receptor. Astfel, deși preocuparea teoreticienilor anglo-americani față de rezultatele potențial pernicioase ale ,,anglocentricitătii”" (Adrian Holliday) în studiile anglofone este în sine etică și lăudabilă, în culturi-gazdă precum cea românească anglocentricitatea poate funcționa ca un catalizator al opoziției și schimbării.

"Poetry makes nothing happen..." (W.H. Auden, "In Memory of W.B. Yeats")

The two divergent positions on the function of poetry in society hail back to the Platonic-Aristotelian dispute over whether poetry is pernicious or cathartic. It is often the case that the statesmen's position does not coincide with the poets'. That, however, is not to say that statesmen think of poetry as either negligible or completely useless; on the contrary, it is said that in the twentieth century the two most involved attitudes towards the sphere of the aesthetic belonged respectively to the political right - which aestheticised politics - and the political left - which politicised the aesthetic. A rapport always exists between literature and politics, even when the former is autonomous of the latter in terms of the institutions of its production and reception: in reflecting and participating in the world, literature is inevitably involved, if not directly with the political, then at least with cultural policies and ideologies. When the literature in question is imported, new dimensions are revealed of the cultural politics of the host country.

Therefore, in what follows I present several aspects concerning the reception and study of English literature in Romania during the second half of the twentieth century, drawing comparisons, sometimes implicitly and at others explicitly, between its relation 
* (See HOLLIDAY, Adrian. Appropriate Methodology and Social Context. Cambridge UP, 1994.)

* (BECK, Ulrich. "The Cosmopolitan Society and Its Enemies", Theory, Culture \& Society 19:1-2 (2002): 17-44.) to politics and Romanian literary studies before and after the 1989 anti-communist Revolution. My main focus is pedagogic, contributing to an increasing body of data concerning the teaching of literature in Romania. Two theoretical axioms concerning literary studies worldwide will be assumed to be true: first, that given the widespread recent critique of Anglocentricity by Anglo-American theoreticians, ${ }^{*}$ self-resistance has become a salient feature of Anglocentricity; and second, that, as Ulrich Beck points out, globalisation's Other is cosmopolitanisation, or «internalised globalisation», ${ }^{*}$ a phenomenon that accounts for the conflicting pulls on institutional policies and practices in Higher Education. With these premises in mind, I first draw a historical overview of the importation of English Studies to Romania, concentrating specifically on the imbrication of classroom practice and cultural impact. Next, I investigate current literary studies by focusing briefly on textbooks, outlining some of the paradoxes attendant on their production and consumption, and raising a few significant questions regarding their rhetoric, utility, collateral effects and politics. In addition to shedding light on the state of the discipline at the present time, this approach will help explain developments in literary translation from the English. I then proceed to show that the respective relationships of textbooks and literary translations to the institution of English Studies are symptoms of broader cultural phenomena in modern Romania.

The introduction of English Studies (ES) in Romania almost a century ago took place against a complicated linguistic background: one half of the country had recently become resolutely Francophile as a mark of modernity challenging the deeply engrained Byzantine-Slavonic heritage; the other half spoke German as their first or second language. Furthermore, the country had acquired a modern sense of its own national identity and was undergoing an accelerated and multifaceted process of modernisation that had begun in the late eighteenth century and is known in Romania as the age of Romanticism. In a topical article, Mihaela Irimia summarises this complex context as follows:

Two sets of mentalities are historically supplanted in the process [of modernising the country in the mid- to late- $19^{\text {th }}$ century]: the Wallachian-Moldavian, with its Byzantine-Slavonic background; and the Transylvanian, with its Austro-Hungarian one. Behind them lies an essentially Romance identity.... In the absence of a 
Western-style Renaissance, with the exception of Polish influences in Moldavia, and of a genuine Enlightenment, with the exception of Şcoala Ardeleană (the Transylvanian School), Romanian Romanticism takes upon itself the task of defending and asserting the foundationalist agenda of European culture at home.*

What emerged was «a belated phenomenon combining Enlightenment with Romantic principles, values and institutions» whose main promoters were poets and historians: Ion Eliade Rădulescu, Mihail Kogălniceanu, Nicolae Bălcescu, Alecu Russo, Dimitrie Bolintineanu, Cezar Bolliac, the bard Vasile Alecsandri and the national poet Mihai Eminescu. ${ }^{*}$ Romanian Romanticism had a very strong civic component that promoted the replacement of the Cyrillic script - formerly imposed by the Slavonic and especially Bulgarian Christian tradition through the schools associated with the Orthodox Church - with the Latin alphabet. The first literary text printed in exclusively Latin script was, significantly, Lord Byron's Don Juan, Cantos I and II, translated from the French (1847).*

A taste was gradually cultivated for Englishness, at first in the shape of a literature and culture, and later as a language to be taught at university level to diplomatic aspirants. In the emerging English departments, ${ }^{2}$ English literature was approached diachronically, with seminars where very close readings of literary texts were done almost at the level of reading comprehension exercises. Contrastive and generative linguistics was soon added, and British and American literature and civilisation courses flourished. No sooner were English programmes established, however, than Romania took a historical turn so drastic that it almost overthrew these achievements: in 1947-1948 the communist regime was established. A handful of scholars continued the work of the earlier pioneers: they wrote textbooks, literary histories, grammars of the English language and dictionaries. The discipline grew, against all odds, during a political regime that disapproved of western capitalism - and the Anglo-American cultural tradition is nothing if not emblematic of capitalism. But just as ES was becoming consolidated, many English departments were closed down throughout the country in the

\footnotetext{
${ }^{2}$ The first English Departments were established by pioneering scholars Petre Grimm, Dragoş Protopopescu, Ana Cartianu, Dumitru Chiţoran and a few others, in the early $20^{\text {th }}$ century, as follows: Jassy, 1917; Cluj-Napoca, 1921; Bucharest, 1936.
}

* (IRIMIA, Mihaela. "English Studies in Romanian Higher Education: A Brief Diachronic View", American, British and Canadian Studies Vol. 14: English Studies in Romania. Gupta, Suman and Ana-Karina Schneider, eds. June 2010: 27-28.)

* (Ibidem: 28.)

* (Ibidem: 29.) 
1980s. They re-emerged in the 1990s to rise to the challenges of an entirely new era in the evolution of the field of ES.

In the early days of ES in Romania, English departments trained mostly diplomats and then gradually also English teachers and translators. Literature and civilisation were regarded as at least equally important disciplines as language, and to this day English programmes throughout the country retain their double focus on language and literature/culture. As the field picked up speed during the ideological thaw of the late 1960s and the 1970s, lectures were geared to offer highly sophisticated information and generate analytic seminar discussions, taking for granted the students' high proficiency in English and broad-ranging familiarity with world culture and literature. The material was organised either strictly diachronically or surveying the evolution of specific genres (drama, fiction, poetry). The survey approach is still extensively practiced in many Romanian universities nowadays - in conspicuous disregard of the much-mediatised canon wars of the west - as it compensates for the relative lack of exposure of our students to the historical and cultural circumstances that have conditioned crucial developments in literary and critical thinking in the Anglophone world. The delivery method however has become more interactive and communicative. Moreover, the stress tends to be on language, rather than literature, classes nowadays. This shift is largely owed to foreign influences on teaching methodology, whether Anglocentric or Eurocentric, although technological and cognitive advances have also had their say, as has the massification of Higher Education. Greater reliance on, and availability of, printed and online resources has been another factor.

Course books are inextricably bound up with the circumstances of a given culture of learning. Depending on the subject they are designed for - language, literature, translation, cultural studies etc. - textbooks enact centrifugal tendencies in different ways and to variable degrees, ranging from being written in Romanian rather than English (though rarely) to conforming to a typically Romanian, information-based approach to teaching and learning methodologies to the detriment of the polemical bend favoured by the Anglo-American educational tradition. The imperative that higher education textbooks labour under in post-EU accession Romania is to help produce and promote a series of internationally marketable competencies and skills that will ensure the graduate's success 
on the labour market. A transnational consumerist logic dictates their priorities and is supported by international organisms such as the Council of Europe, whose Common European Framework of Reference for Languages (2001) and Bologna Process regulate the teaching and assessment of English Studies with the implicit consent of the Romanian Ministry of Education. Yet neither the form nor the content of textbooks is regulated: a standard format recommended by the Ministry exists only for Distance Education course material and it does not differentiate between programmes in the humanities and the sciences. In other words, the responsibility of textbooks in the transmission of knowledge is institutionally acknowledged, even while the specificity of the disciplines they reflect remains indistinct in the eyes of education technocrats.

A few definitions and clarifications of the (self-)regulatory mechanisms in place are in order. Often written in a monologic didactic register that assumes the authority of the master addressing his apprentices, textbooks are teaching/learning facilitators, designed to participate in the dissemination of already existing knowledge and meet the objectives of a curriculum, fulfilling an informative function and making high claims to "expository clarity» and "political neutrality».* This minor genre has a special institutional status, being at once teaching aids, student evaluation benchmarks, faithful reflectors of the state of knowledge in the field, and being marginally imbricated with research assessment exercises. Their correlation with the curriculum both exonerates them from the rigours of innovative and advanced scholarship, and perforce limits their relevance and applicability. More often than not, they are intended to be used in parallel with anthologies and studies published in Britain or the USA, and are explanatory, synthesising or practice-oriented in purport, performing an informative function and at best developing critical thinking, at the expense of concerns with the cultural politics of the information they convey. As such, and unlike scholarly studies and monographs, course books are under no pressure to engage in current western debates or contribute to the evolution of the field, but are rather at liberty to be as expository or as argumentative as is deemed expedient for the practical purposes they serve. ${ }^{3}$ The compensating - though sadly

\footnotetext{
${ }^{3}$ Critical engagement with topical metadisciplinary issues such as canonicity and curricula, the "institutionalisation of social constructionist identity politics” (GUPTA, Suman. Social Constructionist Identity Politics and Literary Studies.
}

* (GUPTA, Suman. Social Constructionist Identity Politics and Literary Studies. Basingstoke: Palgrave-Macmillan, 2007: 278.) 
infrequent, in literary studies textbooks - emphasis on comparative linguistics and intercultural pragmatics and rhetoric, usually absent from English Studies in ordinarily Anglophone countries, results in an unmistakably non-English - at times distinctively Romanian - textualisation of the English language or Anglophone literatures and cultures.

These divergent attitudes towards the disciplines they summarise and facilitate access to, like many others of their features, stem from the special conditions of their production, as well as their temporally and institutionally limited usefulness. The production of course books in Romania is something of a cottage industry: published by local university presses in small circulations, often at the author's expense, with only minimal peer reviewing and no largescale distribution scheme, textbooks are neither a financially profitable nor a prestige-accruing enterprise for their authors. Rather, their utility, though often restricted to serving a curriculum devised at a specific university, is strictly pedagogic. Consequently, textbooks are bound by their own specific rules of representation and intertextuality, and rife with markers of pedagogic pragmatics, and they register patterns of development in the institutional practice of the discipline (i.e., in curricula and syllabi). It is for reasons such as these that a critical examination of the rhetoric, methodology and thematics of course books, anthologies and activity books currently in use is relevant and inevitable to any appraisal of the latest directions in literary studies in countries situated on the margins of the English-speaking community such as Romania.

A complex set of contingencies, not all of them academic, have determined this evolution. The academic factors have to do with frequent curricular revisions and institutional reforms variously undertaken over the past twenty years, the decentralisation of the higher education system and its massification in Romania, and the changes in teaching methodologies and classroom power dynamics throughout the English-speaking world. Student-centred, dialogic

Basingstoke: Palgrave-Macmillan, 2007: 276), the definition of culture or the mission of Higher Education is marginalized or obstructed, though such issues may sometimes be thematised. Some textbooks' indebtedness to the discourse of western critical thinking and disciplinary development (variously defined as Anglocentricity or westerncentricity) is therefore indicative of the extent to which textbooks participate divergently in the local institutionalised practice of the discipline, in view of both responding to the demands of social participation and meeting the standards of western scholarship. 
approaches to education, encouraged by British Council-sponsored teacher training sessions, have helped put a more collegial face on the professor-student relationship. They have effected what might be called an enhanced awareness that «what» we teach are students, not disciplines, ${ }^{*}$ and turned English departments throughout the country into flagships in teaching methodology. The non-academic factors include variables and contingencies that pertain to the students themselves: despite the fact that instruction in the foreign languages in post-1989 Romania starts in second form and sometimes in kindergarten (as opposed to the fifth form before 1989), the level of student literacy in English is far from uniformly high nowadays. As this renders uncertain the extent to which students can follow the flow of information delivered orally, let alone make notes of it, there has been increasing pressure on lecturers to make the content of their lectures available in book format. Sadly, lecture-note volumes, to the extent that they are compendia of the minimum information needed to pass exams, are not stimulative of either further reading or synthesising, and often fail to produce knowledge or competences beyond the salvific exercise of accumulating credits. They also effect the abandonment of library research practices and the ossification of the skills and habits of mind associated with it.

Attempts to bring in the students' culture-specific home context are often met with less than warm responses. One may speculate as to the reasons behind this attitude among current students. Prestige accrual, like good marks in evaluations, depends on the accumulation of knowledge about their field of studies rather than their own culture. With many of them, for whom the study of foreign languages is a stepping stone towards a job abroad or in a multinational corporation, it is often a matter of avoiding clutter. Proliferation of this attitude seems to be synchronous with the massification of Higher Education. In all fairness it must be added that Romanian education is traditionally geared towards information memorisation of a single perspective, rather than interpretation/ critical engagement with multiple perspectives, and in some areas current communicative teaching methods have had only a very limited impact against the perceived authority of the printed text.

A more complex situation is signalled when an MA student argues in her dissertation that Romanian poet Ion Pillat's 1933 translation of TS Eliot's Wasteland is inadequate in that the trans-
*(GREGORY, Marshall. “Do We Teach Disciplines or Do We Teach Students?" Profession 2008. New York: MLA, 2008: 117.) 
* (BECK, op. cit.: 27.)

* (Ibidem: 27.)

* (Ibidem: 18.)

* (CORNIŞ-POPE, Marcel. The Unfinished Battles. Romanian Postmodernism before and after 1989. Iaşi: Polirom, 1996: 62.) lator deploys an archaizing and occasionally regional language that may well echo relevant Romanian myths and legends but fails to resonate with the concerns of modern man in what had begun to become, with the advent of the First World War, a globalised world. There is no snobbish or pragmatic concern here to display allegiance to English literature, but rather an erasure of the inside-outside/ centre-margin dichotomies, and of the sense that the home context need remain external to the study of a foreign language as something against which knowledge in such a field can be measured or to which it can be made relevant. While the importance of translation from one language to another remains in place, there is increasingly less of a sense that the text also travels from one culture into another and more of a blurring of boundaries that is the upshot of globalisation, the EU and modernity generally. This objection can be extrapolated to textbooks if we agree that the local production and circulation of textbooks is a translation of the genre - and often of actual, already published native-speakerist textbooks - into the local cultural and academic context: as education systems come under pressure to conform to internationally prescribed benchmarks, teach transferable skills and accommodate exchanges, it is the codified conventions of the syllabus rather than the home background that determine variation. German sociologist Ulrich Beck distinguishes between nations and cosmopolitan societies along the lines of such divergent attitudes to a collective past and future, respectively.* He calls this tendency of the "collective future consciousness» to take over the role of tradition and memory in cosmopolitan societies a «re-traditionalization» and avers that it happens not only in culture, but also in the social and political spheres.*

Our unproblematising endorsement of Anglocentricity often American-centricity; cosmopolitanism? - is severally overdetermined. On the one hand, indeed, there are all the usual motivations, having to do with the globalised world, international labour markets, cultural exchanges, and the prestige accruing to a dialogic cosmopolitan imagination.* On the other, however, at the risk of homogenising and simplifying so complex an entity, it must be said that Romanian culture traditionally welcomes western influence as a kind of historical compensatory mechanism.* Romania's geographical situation on the margins of Europe and historical position at the crossroads of various imperial ambitions - Ottoman, Polish, Russian, Austrian, Austro-Hungarian, Russian again 
- have given rise to a sense not only of its marginality and powerlessness but also of the exclusions to which it has been susceptible despite its Christian tradition and Romance language. To compensate, ever since the Renaissance, studying at the universities of the west (Bologna, Paris, Vienna, Heidelberg, and later England, etc.) or bringing scholars from those universities to teach in Romanian schools was a matter of prestige for the local aristocracy. Our first universities in the mid-19 $9^{\text {th }}$ century, like the earlier «academies,» were based on western models and foreign professors were invited to teach there; the first Chair of English at the University of Bucharest was an Englishman, John Burbank (1936), and Petre Grimm, who established the first English Lektorat at Cluj-Napoca in 1919, had studied English at the Sorbonne and the University of Freiburg.* English literature, and drama in particular, became increasingly well known to the Romanian reading and theatre-going public throughout the $19^{\text {th }}$ century, the plays of Shakespeare for instance being recommended as a model to be followed in the creation of a national theatrical culture.* This westward-looking emulative ambition was to set a pattern for much of the literary and cultural output throughout the $20^{\text {th }}$ century and beyond. When historical circumstances became inimical to such tendencies in the late 1940s through the early 1960s, a measure of emulation survived even in the face of severest censorship. It is for the cultural privations of the communist regime in particular that Romanians compensate - sometimes over-compensate - post 1989.

The relationship between literary translation and the study of Anglo-American literature further illustrates cultural policies in Romania before and after 1989. Translations of foreign texts into Romanian have had a long and convoluted history. ${ }^{4}$ Before the institutionalisation of English Studies in the 1920s and 1930s, and even shortly after, much English literature reached the Romanian readership via French, German and sometimes Greek translations that were then rendered in Romanian. Such was the case, for instance, of early translations of Victorian novels. The professionalisation of translation in Romania was slow to follow in the

\footnotetext{
${ }^{4}$ I speak elsewhere about the professionalization of literary translation in Romania and the attendant cultural politics. See SCHNEIDER, Ana-Karina. "Literary Translation: Between Mediation and Interpretation", in American, British and Canadian Studies. Vol. 14: English Studies in Romania. Gupta, Suman and AnaKarina Schneider, eds. June 2010: 104-118.
}

* (DOROBĂT, Dumitru. "English Studies at 'Alexandru Ioan Cuza' University of laşi", American, British and Canadian Studies Vol. 14: English Studies in Romania. Gupta, Suman and Ana-Karina Schneider, eds. June 2010: 12-13.)

* (Ibidem: 12 .) 
wake of ES: while most graduates of the newly established English departments took the as-yet untrodden road of teaching, for more than half of the twentieth century translations were undertaken by erudite amateurs with a vast knowledge of foreign languages, or even, sometimes, by established Romanian writers with scant knowledge of English who worked in tandem with English language specialists providing cribs.

The communist «literature for the masses» policy, however, gradually led to the professionalisation of the field. Concomitantly, communist censorship filtered what was regarded as appropriate reading for the "good comrade» and selectively blocked out much literature that was deemed potentially dangerous to his morals and ideology. This resulted in a typically paradoxical situation: on the one hand, if a writer's politics were regarded as pernicious, his books were banned; on the other, if the same writer was awarded, say, the Nobel Prize in literature, his books were (sometimes selectively) translated and care would be taken to explain away - sometimes to misrepresent, quite deliberately - his «misguided» social ideas. Such was the case of William Faulkner and Ernest Hemingway, who were only translated into Romanian in the 1960s, after they had garnered the Nobel and when the communist regime in Romania was undergoing de-Stalinisation: Faulkner was hailed as a champion of the poor and the downtrodden whereas Hemingway was shown to be a staunch castigator of the shallowness of moneyed Americans. Falsifying as such interpretations may seem to the Faulkner or Hemingway reader, they effectively made it possible for these writers to reach the Romanian readership and be included in school curricula.

It is worth noting in this respect that pre-1989 both curricula and literary criticism were formally restricted to texts which were available in Romanian translation and thus accessible to the censors, whereas private ownership of books in languages other than Romanian was officially banned. The ban was not always very effectively enforced, and books did circulate in the original or in foreign translations through networks based on trust; additionally, university libraries held some world literature in the original, which students and professors could consult for language-learning purposes. Consequently, the impact of international literature was much stronger and more insidious than might be expected. Nonetheless, this circumstance illustrates the role of translation in facil- 
itating access to foreign cultures and explains the eagerness with which translations from the English were generally met by critics and book reviewers of the literary press.

Significant changes after 1989 reflect massive shifts in the understanding of the position and role of translation in culture and the definition of culture itself. English departments across the country now offer Masters programmes in ESP translation as well as Bachelor degrees in Applied Modern Languages, responding to the acutely felt need for language specialists to mediate emerging multinational economic and technological exchanges and fill the gaps left behind by communist cultural censorship. For a while, literary translation seemed to lag behind in terms of its disciplinisation, but is now gradually picking up speed at the behest of influential translation studies programmes at the universities of Jassy and Bucharest, and of the continuing demand for new translations of both older and contemporary literature in English. Conversely, translations from the Romanian still have considerable difficulty finding their way to western audiences and Romanian studies is only offered at a handful of schools throughout the world, usually as part of post-communist or Slavic and East-European Studies.

This asymmetry of cultural exchanges reflects the positioning of Romanian culture vis-à-vis western sources. As the language of a small, constantly emergent, variously victimised and marginalised East-European country, Romanian consistently finds itself at the receiving end of the exchange. The implicit acceptance of a weak position is evident in exercise books published before 1989 by translation specialists such as Leon Leviţchi, Andrei Bantaş, Lidia Vianu, etc. In an attempt to compensate for the comparative lack of serious theorising, they devised practice books with suggested model translations in the key to the exercises. While these were mainly intended as language-learning instruments, they helped propagate a monolithic view of English, rather than invite instructive comparisons between the models and the student's solutions. Somewhat like Roger Ascham's «double translation,» their method pivots on the implication that the teacher's instruction addresses the generative system, whereas the imponderable features of the surface structure can only be learnt «humbly» from the original.* This principle of emulation derived from the practice of translation from the English classics reveals reverence towards the «language of Shakespeare» in its various chronotopical avatars and an intense

* (LEVITुCHI, Leon. Îndrumar pentru traducătorii din limba engleză în limba română. Bucureşti: Centrul de multiplicare al Universităţii din Bucureşti, 1974: 293.) 
* (HOLLIDAY, Adrian. Appropriate Methodology and Social Context. Cambridge UP, 1994.)
* (MARINO, Adrian. Comparatism şi teoria literaturii. Trans. Mihai Ungurean. laşi: Polirom, 1998: 5-6.) concern, pedagogic in purport, with the improvement and elevation of the Romanian language. Indeed, it is only more recently that Romanian literary translations have begun to break the mold of what is known as «literary» or "national language,» the standard, grammatically accurate, lexically proper idiolect.

It is precisely such monolithic, restrictive perceptions of English as both a language and a discipline that theoreticians of pedagogy such as Adrian Holliday and others are apprehensive of when they warn against the pernicious effects of too slavish an observance of «native speakerist» models.* Nevertheless, in Romanian culture, far from constituting a disadvantage, the acknowledgement of this subordinate position contributes to a constant and ambitious redefinition and re-positioning of cultural and sometimes even political priorities. In other words, it instantiates the strategic imbrication of translatio studii with translatio imperii. This collocation signals the potential of translatio to transcend the traditional association with rhetoric, the transference of meaning and the supplementing of gaps in a language. Rather, it carries an extralinguistic weight that synthesises the cultural turn in the definition of translation. The full implications of this understanding of translation were particularly evident during the communist regime when, although western literatures and cultures were castigated as vehicles of corrupting ideologies, prominent western writers were nonetheless opportunistically appropriated and capitalised on in order to claim for communism an open-mindedness and progressiveness that contributed positively to further cultural and even economic exchanges.

Conversely, on the margins of the communist regime, scholars sometimes embraced the view of Romania's marginal and subordinate position for clearly subversive purposes. Despite state control and internalised censorship, the dominant move in pre-1989 literary criticism was away from the monolithic discourse of Stalinist ideology, towards a thorough synchronisation with kindred western trends. In a book originally published in France in 1988, Romanian comparative literature specialist Adrian Marino lists the advantages pertaining to the marginal condition of the East-European writer, of which he foregrounds the freedom to choose the intellectual fashions that one follows, and the distance and tabula rasa afforded by our non-subservience to any tradition or institutionalised school.* In the following years especially, the late com- 
paratist became increasingly concerned with solutions for the integration of our marginalised literature in the world canon and with mediating between minor and major cultures. This is a case of a minor culture embracing its marginality as a way of affirming its resistance to the hegemony of western systems.

The typical narrativisation of Romanian culture emphasises the fact that the most seminal changes - such as the «reversed innovatorism» of the 1960s and 1970s* and the postmodernism of the 1980 s - came from within the Romanian artistic and critical thinking. This self-representation informs the work of theoreticians as diverse as Adrian Marino, Nicolae Balotă, Marcel Corniş-Pope, Ion Bogdan Lefter, Magda Cârneci etc. This is not to deny that there are deep filiations with western cultures, ranging from direct imitation to under-the-board influences that even penetrated the Iron Curtain. However, the Romanian cultural picture is autochthonous in a fundamental sense: the effort to reassess the cultural heritage and recuperate its values always stemmed from an inner self-consciousness and a will to progress. This internal dynamics is a constitutive feature of Romania's periodic process of identity definition. Cârneci quotes Gianni Vattimo speaking about «the 'salvation through poverty' and the 'providence of discrepancy' of the marginalized cultures and disinherited regions, inside the process of globalization, as a unique chance for preserving a possible way out of the very dialectics of the western world and its dominant metaphysics».* Romania's condition allowed its culture to adopt selectively a variety of influences, most conspicuously the postmodern fiction and Beat poetry of America, at the height of communist isolationism and repression in the 1980s.

For all this optimism, the very special circumstances shaping Romanian culture and critical discourse for about a third of the $20^{\text {th }}$ century resulted in a reluctance among scholars to take the «theoretical turn» - otherwise known as poststructuralist and, more significantly, self-reflexive - that became the dominant discourse of literary and cultural studies in the western world in the 1970s and 1980s. This resistance was largely caused by the rejection of the very idea that anything useful might come out of Marxism. For more than a decade longer, Romanian literary studies was at variance with western evolutions, remaining resolutely formalist and hermeneutic in purport. Once more, English Studies was a flagship of innovation in this respect: enlisting the expertise of an
* (LEFTER, lon Bogdan Literature in the ' 60 s and '70s. The Experiment. In Spiridon, Monica, lon Bogdan Lefter, and Gheorghe Crăciun. Experiment in Post-War Romanian Literature. Trans. Della Marcus, Ruxandra-loana Patrichi, and David Hill. Piteşti: Paralela 45, 1999: 36. )

* (CÂRNECl, Magda. Art of the 1980s in Eastern Europe. Piteşti: Paralela 45, 1999: 109.) 
ever more visible diaspora, English literature specialists faced the need to problematise our relationship with our communist past and overcome this prejudice by resorting to approaches developed in Anglo-American cultural and critical theory. Thus, in the late 1990s, postcolonialism seemed like a good place to start in theorising communism, but gradually post-communist studies has come to be recognised as a distinct field. Although it seldom focuses on literature in English, that too is not unheard of - see for instance studies of Saul Bellow's The Dean's December (1982), Julian Barnes's The Porcupine (1992), Patrick MacGuiness's more recent The Last Hundred Days (2011), or The Train to Trieste (2008) and Burying the Typewriter (2012) by Romanian diasporans Domnica Rădulescu and Carmen Bugan, respectively. More often than not, however, the contribution of English literary studies is theoretical and comparatist, capitalising on Anglists' familiarity with the Anglo-American polemical, self-reflexive critical tradition.

Much of the theory published in recent years is the response to a deeply felt need to reassess the critical inheritance bequeathed by previous generations and find the points at which post-communist literary studies can insert itself into a tradition that is both thoroughly Romanian and synchronous with western developments. It is often metacritical and synthetic, and a great portion of it has been written by theoreticians who have lived abroad, having all the advantages of cultural exchange and critical distance. Secondly, post-1989 literary studies, benefiting from both hindsight and freedom of speech, offers a far more complex, multifaceted picture of Romanian culture than its predecessors. Nicolae Balotă, Magda Cârneci, Marcel Corniş-Pope, Ion Bogdan Lefter, Christian Moraru, Adrian Oţoiu, Andrei Terian, among many others, write retrospectively on the apparatuses - from propaganda to the Writers' Association, from threats to the promise of privilege, and from censure to internalised censorship - devised by the communist party in Romania in order to preserve the monolithic character of its discourse, and implicitly of its social and political power. Their writing foregrounds the various ways in which much valuable critical thinking bypassed the vigilance of the ideological watchdogs of communism and established a tradition that is still, to a large extent, vital and active nowadays. In comparative terms, then, it could be said that literature and literary studies in Romania post-1989 have enjoyed more freedom to do what they do best: 
«Teach the free man how to praise,» in the concluding words of W.H. Auden's poem quoted above.

To conclude, if Romania seems traditionally only too eager to implement Anglocentric communicative teaching methods and Eurocentric or western-centric pedagogic philosophies, it is out of an internalised, somewhat fatalistic, acceptance of its status as a minor culture on the margins of Europe, but also out of a strategic understanding of the ways in which this asymmetric cultural exchange can contribute to transfer a measure of power to the receiving culture. Viewed in this light, neither Anglo-centrism or «native speakerism,» nor Eurocentrism seems to be quite as oppressive of the local context as they are sometimes made out to be.

Ana-Karina Schneider é Professora Associada de Inglês da Universidade Lucian Blaga de Sibiu, na Romênia. Publicou artigos sobre a recepção crítica de William Faulkner, a prosa de ficção em inglês, a traduçáo literária, estereótipos e práticas de leitura e os Estudos Ingleses no ensino superior romeno. É editora da revista American, British and Canadian Studies, da Sociedade Acadêmica Anglófona da Romênia. E-mail: <karinaschneider2001@yahoo.co.uk> 